ISSN: 1858-4837; E-ISSN: 2598-019X

Volume 15, Nomor 1 (2019),

https://jurnal.uns.ac.id/region

DOI: $10.20961 /$ region.v15i1.24384

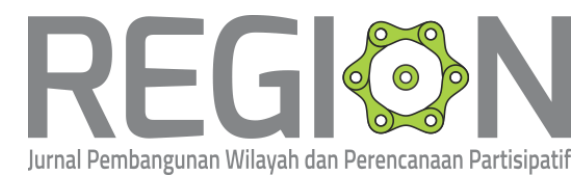

\title{
Preferensi pemilihan moda transportasi oleh wisatawan domestik di Kota Surakarta
}

\author{
The preference of transportation mode choice by domestic tourist in Surakarta
}

\author{
R A Nugroho1, E B Santoso², dan C Susetyo² \\ ${ }^{1}$ Perencanaan Wilayah dan Kota, Institut Teknologi Kalimantan \\ ${ }^{2}$ Perencanaan Wilayah dan Kota, Institut Teknologi Sepuluh Nopember
}

Corresponding author's email: arif.rizky@itk.ac.id

\begin{abstract}
Abstrak. Pariwisata sangat erat kaitannya dengan sektor transportasi. Bagi pariwisata, sektor transportasi berfungsi sebagai penyedia akses menuju suatu tempat tujuan. Hal ini berarti fungsi utama transportasi sangat erat kaitannya dengan aksesibilitas. Dengan kata lain, sektor transportasi memudahkan penggunanya mengunjungi daerah tertentu, misalnya objek wisata. Penelitian ini bertujuan untuk mengetahui preferensi pemilihan moda transportasi oleh wisatawan domestik di Kota Surakarta. Paradigma dalam penelitian ini adalah rasionalistik. Analisis dilakukan menggunakan analisis korespondensi untuk mengetahui hubungan antara kategori moda transportasi pilihan wisatawan dan kategori alasan pemilihannya. Hasilnya diketahui jika wisatawan banyak memilih menggunakan sepeda motor karena alasan bebas macet, santai, murah, dan efisien.
\end{abstract}

Kata Kunci: Aksesibilitas; Moda Transportasi; Pariwisata; Preferensi; Wisatawan

\begin{abstract}
Tourism has a deep connection to transportation sector. Transportation sector opens access to destination. It means, the main function of transportation heavily related to accessibility. In other word, transportation sector could make possible for its user to travel to certain area with ease, for example to the tourism destination. Thus, this study aims to identify the tourist's preference of transportation mode choice of domestic tourist in Surakarta. Paradigm used in this study is rationalistic. Analysis method used is correspondence analysis. Analyzes were performed using correspondence analysis to determine the relationship between modes of transport category rating and category selection reasons for their
\end{abstract}

Received: October 03, 2018; Accepted: January 21, 2019; Available online: January 10, 2020

Copyright $\odot$ 2020, REGION: Jurnal Pembangunan Wilayah dan Perencanaan Partisipatif 
choice. The result shows that most of tourists use motorcycle because it is easier to move, easier to use, cheaper, and more efficient.

Keywords: Accessibility; Preference; Transportation Mode; Tourism; Tourist

\section{Pendahuluan}

Pariwisata sangat erat kaitannya dengan sektor transportasi. Bagi pariwisata, sektor transportasi berfungsi sebagai penyedia akses menuju suatu tempat tujuan [1]. Aktivitas kepariwisataan banyak bergantung pada sektor transportasi dan telekomunikasi. Sektor transportasi yang berkembang berarti mendorong kemajuan sektor pariwisata atau sebaliknya, ekspansi dalam industri pariwisata dapat menciptakan permintaan transportasi untuk dapat memenuhi kebutuhan wisatawan [2]. Menurut Moeis dan Fahmi [3], hal ini berarti fungsi utama transportasi sangat erat kaitannya dengan akasesibilitas. Dengan kata lain, sektor transportasi memudahkan penggunanya mengunjungi daerah tertentu, misalnya objek wisata.

Perkembangan sektor pariwisata di Indonesia saat ini mengalami peningkatan yang amat pesat sebagai hasil dari percepatan pembangunan infrastruktur transportasi. Pemerintah Indonesia menetapkan target kunjungan wisata pada tahun 2019 mencapai pergerakan 275 juta jiwa bagi wisatawan nusantara serta Indeks Daya Saing Pariwisata Indonesia menempati peringkat 30 [4].

Negara dengan indeks daya saing pariwisata terbaik di Asia Tenggara adalah Singapura. Pencapaian itu diperoleh dengan mengandalkan sektor transportasi yang dimilikinya, khususnya transportasi darat (peringkat 2 dunia) [5]. Singapura juga merupakan salah satu negara dengan transportasi umum paling efisien di dunia dengan memperhitungkan faktor waktu perjalanan, tarif, tingkat kepadatan penumpang, dan kemudahan [6]. Di sisi lain, sektor transportasi yang tidak terbangun bisa menjadi penghambat serius dalam mengembangkan potensi pariwisata. Pulau Raja Ampat di Provinsi Papua Barat, Indonesia memiliki potensi pariwisata yang cukup besar. Raja Ampat memiliki keanekaragaman biota laut tertinggi di dunia. Namun, akses transportasi yang kurang memadai menghambat pengembangan potensi pariwisata di Raja Ampat. Tidak ada penerbangan langsung ke Raja Ampat merupakan salah satunya. Hal ini menyebabkan mahalnya biaya yang harus dikeluarkan untuk pergi ke lokasi tersebut [7].

Berdasarkan RTRW Kota Surakarta tahun 2010-2030, Kota Surakarta diarahkan untuk pengembangan potensi Kota Surakarta sebagai Kota yang berbasis budaya yang didukung oleh sektor perdagangan, jasa, pariwisata, olah raga dan industry [8]. Pada bulan Februari tahun 2016 sejumlah 617.489 wisatawan mengunjungi Kota Surakarta yang terbagi atas 613.034 wisatawan domestik dan 4.455 wisatawan mancanegara [9]. Untuk menarik minat wisatawan, Pemerintah Kota Surakarta terus melakukan upaya melalui pengadaan eventevent religi serta memperbanyak kerjasama dengan maskapai penerbangan [9]. Selain itu, bisnis kuliner juga merupakan salah satu sektor unggulan pariwisata di Kota Surakarta. Hal 
ini dapat dilihat bahwa pada tahun 2015 terdapat 859 restoran atau terjadi peningkatan sebesar 250\% dibandingkan tahun 2014 [9].

Kota Surakarta tidak hanya memiliki potensi wisata yang cukup besar namun juga menghadapi masalah transportasi. Terjadi peningkatan kepadatan arus lalu-lintas yang cukup parah pada jam-jam tertentu. Hal ini merupakan akibat pertumbuhan kendaraan di Kota Surakarta sangat cepat. Sistem Administrasi Manunggal Satu Atap (Samsat) Surakarta mencatat sekitar 470 ribu kendaraan dengan plat AD. Selain itu, pertumbuhan jumlah kendaraan mencapai $10 \%$ per tahun [10]. Pada saat liburan, kemacetan yang timbul semakin parah dengan banyaknya kendaraan dari luar kota yang masuk ke Kota Surakarta yang volumenya mencapai hingga 45\% [11]. Akibatnya, potensi wisata yang dimiliki Kota Surakarta tidak dapat dikembangkan secara maksimal akibat adanya permasalahan sektor transportasi.

Menurut Holloway dalam Kusbiyantoro [12], wisatawan adalah seseorang yang mengadakan perjalanan untuk melihat sesuatu yang lain dan kemudian menyatakan keluhan apabila membayar sesuatu yang tidak sesuai. Hal tersebut menggambarkan bahwa wisatawan selain datang untuk mengunjungi objek, namun juga membutuhkan pelayanan untuk memperoleh hal yang mereka inginkan. Wisatawan juga dapat diartikan sebagai semua orang yang memenuhi syarat yaitu: (1) bahwa mereka meninggalkan rumah kediaman mereka untuk jangka waktu kurang dari satu tahun dan (2) bahwa sementara mereka bepergian, mereka mengeluarkan uang di tempat yang mereka kunjungi tanpa bermaksud mencari nafkah ditempat tersebut [13]. Marpaung [14] berpendapat bahwa wisatawan adalah orang yang bertempat tinggal disuatu negara tanpa memandang kewarganegaraan, berkunjung kesuatu tempat pada negara yang sama untuk jangka waktu lebih dari 24 jam yang tujuan perjalanannya dapat diklasifikasikan pada salah satu hal seperti memanfaatkan waktu luang untuk rekreasi, liburan, kesehatan, pendidikan, keagamaan dan olah raga. Lainnya adalah bisnis atau mengunjungi keluarga. Wisatawan nusantara atau wisatawan domestik adalah seseorang yang melakukan perjalanan di wilayah teritori suatu negara, dalam hal ini adalah Indonesia, dengan lama perjalanan kurang dari 6 bulan dan bukan bertujuan untuk memperoleh penghasilan di tempat yang dikunjungi. Bukan pula merupakan perjalanan rutin (sekolah atau bekerja), dengan mengunjungi objek wisata komersial, dan atau menginap di akomodasi komersial, dan atau jarak perjalanan lebih besar atau sama dengan 100 (seratus) kilometer pergi-pulang .

Preferensi memiliki arti prioritas, pilihan, kecenderungan dalam memilih atau kesukaan terhadap sesuatu berdasarkan kepada Kamus Besar Bahasa Indonesia. Dalam hal ini berarti preferensi berkaitan dengan rasa kesukaan, pilihan atau suatuhal yang disukai konsumen. Pilihan tersebut merupakan serangkaian pilihan yang didefinisikan dan dibatasi oleh batasan atau kendala anggaran [15]. Keputusan untuk memilih suatu hal yang menurut mereka lebih disukai dari yang lain biasanya antara satu orang dengan orang lain tidak sama [16]. Berdasarkan penjelasan di atas, maka dapat disimpulkan jika preferensi merupakan suatu pilihan yang diputuskan oleh konsumen terhadap sesuatu hal. Pilihan tersebut biasanya berbeda antara satu orang dengan lainnya karena setiap orang memiliki kendala atau 
batasan yang berbeda pula. Dalam penelitian ini, preferensi yang dimaksud adalah preferensi dari wisatawan sebagai pengguna transportasi umum.

Dalam memilih moda transportasi, banyak faktor yang mempengaruhi pemilihannya. Namun kebanyakan memilih berdasarkan faktor biaya karena semakin mahal biaya yang dikeluarkan maka akan semakin mengurangi pendapatan mereka. Menurut Arofah et al [17], hal yang dipertimbangkan dalam memilih moda transportasi adalah biaya yang akan dikeluarkan, jarak yang ditempuh, kepemilikan kendaraan, dan faktor kesukaan karena penglaju lebih menyukai alat transportasi tersebut. Ditambahkan oleh Trianisari et al [18], memilih moda angkutan di daerah perkotaan bukanlah proses acak, melainkan dipengaruhi oleh faktor kecepatan, jarak perjalanan, kenyamanan, kesenangan, biaya keandalan, ketersediaan moda, ukuran kota, serta usia, komposisi, dan status sosial-ekonomi pelaku perjalanan. Semua faktor tersebut dapat berdiri sendiri maupun saling bergabung. Menurut penelitian yang telah dilakukan oleh Trianisari et al [18], diperoleh bahwa alasan pemilihan moda transportasi terdiri dari bebas macet, bebas polusi, bebas biaya, hemat biaya, hemat tenaga, jalur bebas hambatan, jarak dekat, nyaman, optimal waktu, adanya perbaikan angkutan umum, sehat, dan tidak ada masalah parkir. Maka dalam penelitian ini perlu diketahui alasan wisatawan dalam memilih moda transportasi tertentu dalam melakukan aktivitas di Kota Surakarta.

Berdasarkan paparan latar belakang penelitian, berkembang pertanyaan penelitian tentang bagaimanakah preferensi wisatawan di Kota Surakarta dalam memilih moda transportasi dan alasan yang mendasarinya. Oleh sebab itu, tujuan penelitian ini adalah menemukenali preferensi pemilihan moda transportasioleh wisatawan domestik di Kota Surakarta.

\section{Metode analisis}

Paradigma dalam penelitian ini adalah rasionalistik. Paradigma rasionalistik memandang bahwa sebuah realitas sosial itu didasarkan kepada teori-teori yang ada yang kemudian dihubungkan dengan data-data empirik di lapangan. Metode pengumpulan data adalah bagian dari instrumen pengumpulan data yang menentukan berhasil atau tidaknya suatu penelitian [19]. Oleh karena itu pengumpulan data haruslah direncanakan secara matang sehingga dapat optimal sesuai dengan tujuan dan sasaran yang hendak dicapai. Dalam penelitian ini, data yang dibutuhkan merupakan data primer. Pengumpulan data primer ialah pengumpulan data yang dilakukan untuk memperoleh data yang tidak terdapat pada instansi melainkan langsung di lapangan. Data dikumpulkan melalui pembagian kuesioner kepada responden. Kuesioner adalah seperangkat daftar pertanyaan tertentu yang disusun secara sistematis dan lengkap. Kuesioner dimaksudkan sebagai suatu daftar pertanyaan untuk memperoleh data berupa jawaban-jawaban dari para responden, yaitu orang yang memberi jawaban. Kuesioner ini berfungsi untuk mengetahui preferensi pemilihan moda transportasi oleh wisatawan domestik di Kota Surakarta.

Populasi dalam penelitian ini adalah jumlah wisatawan domestik yang mengunjungi Kota Surakarta. Berdasarkan pendapat Sugiyono [20], populasi merupakan wilayah generalisasi yang terdiri atas objek/subjek yang mempunyai kualitas dan karakteristik tertentu yang 
ditetapkan oleh peneliti untuk dipelajari dan kemudian ditarik kesimpulannya. Sedangkan sampel adalah bagian dari jumlah dan karateristik yang dimiliki oleh populasi tersebut. Bila populasi besar, dan penelitian tidak mungkin mempelajari semua yang ada pada populasi, misalnya keterbatasan dana, tenaga dan waktu maka penelitian dapat menggunakan sampel yang diambil dari populasi tersebut [20]. Populasi dalam penelitian ini tergolong kepada indefinite population atau populasi yang tidak diketahui jumlahnya secara pasti. Untuk menghitung jumlah sampel dari populasi yang tidak diketahui jumlahnya maka dapat digunakan rumus Wibisono sebagai berikut :

$$
n=\left(\frac{Z_{\alpha / 2} \sigma}{e}\right)^{2}
$$

Dimana :

$\mathrm{n} \quad=$ jumlah sampel

$\mathrm{Z} \alpha=$ tabel distribusi normal sampel $=1,96$

$\Sigma \quad=$ standar deviasi populasi $=0,25$

$\mathrm{E} \quad=$ tingkat kesalahan $=0,05$

Dengan tingkat kepercayaan 95\% diperoleh sampel dengan jumlah 96,04 orang atau dilakukan pembulatan sehingga diperoleh jumlah 100 orang untuk masing-masing populasi. Teknik sampling yang digunakan adalah sampling accidental. Teknik pengambilan sampel ini ditentukan berdasarkan faktor spontanitas dimana siapa saja yang secara kebetulan bertemu dapat dijadikan sampel jika dirasa cocok sebagai sumber data [20].

Untuk mengetahui preferensi wisatawan dalam memilih moda transportasi akan digunakan metode analisis korespondensi. Analisis korespondensi merupakan salah satu teknik dalam multivariat yang merupakan gabungan dari teknik reduksi data dan pemetaan persepsi. Salah satu tujuannya adalah untuk mengetahui kedekatan atau keterkaitan suatu kategori pada satu peubah dengan kategori peubah lainnya. Tahapan analisis dimulai dengan mengolah data teks yang diperoleh dari kuesioner yang telah diisi, kemudian jawaban yang telah diisi akan dikategorikan atau dikelompokkan secara lebih umum sehingga dapat diketahui frekuensi munculnya jawaban tertentu. Pada penelitian ini, objek yang diamati adalah hubungan antara kategori moda transportasi pilihan wisatawan dan kategori alasan pemilihannya digunakan analisis korespondensi. Perhitungan analisis korespondensi dilakukan menggunakan perangkat lunak SPSS 23.

\section{Pembahasan}

Berdasarkan hasil wawancara yang telah dilakukan kepada seluruh responden yang berjumlah 100 orang maka diperoleh hasil tentang persentase distribusi preferensi wisatawan terhadap moda transportasi yang dipilih untuk dapat mengunjungi tempat wisata tujuan. Berdasarkan tabel 1, terlihat bahwa $61 \%$ wisatawan memilih sepeda motor sebagai moda transportasi pilihannya, $27 \%$ memilih menggunakan mobil, $11 \%$ memilih menggunakan Batik Solo Trans, dan hanya 1\% memilih menggunakan travel. Dalam memilih alasan pemilihan moda transportasi yang digunakan, wisatawan mengutarakan beragam alasan. Data tersebut kemudian dikelompokkan menjadi enam kategori yang mewakili 
alasan tersebut. Terdapat alasan yang muncul di semua pemilihan moda, yaitu alasan efisien. Baik wisatawan yang memilih menggunakan sepeda motor, mobil, Batik Solo Trans, maupun travel mengutarakan alasan ini (lihat Tabel 1).

Tabel 1. Pemilihan moda transportasi dan alasannya.

\begin{tabular}{llllll}
\hline & Sepeda Motor & Mobil & Batik Solo Trans & Travel & Total \\
\hline \multirow{2}{*}{ Murah } & 12 & 0 & 2 & 0 & 14 \\
& $12 \%$ & $0 \%$ & $2 \%$ & $0 \%$ & $14 \%$ \\
Efisien & 35 & 8 & 1 & 1 & 45 \\
& $35 \%$ & $8 \%$ & $1 \%$ & $1 \%$ & $45 \%$ \\
Bebas Macet & 11 & 0 & 0 & 0 & 11 \\
& $11 \%$ & $0 \%$ & $0 \%$ & $0 \%$ & $11 \%$ \\
Nyaman & 0 & 19 & 3 & 0 & 22 \\
\multirow{3}{*}{ Santai } & $0 \%$ & $19 \%$ & $3 \%$ & $0 \%$ & $22 \%$ \\
& 2 & 0 & 0 & 0 & 2 \\
Terjangkau & 1 & $0 \%$ & $0 \%$ & $0 \%$ & $2 \%$ \\
& $1 \%$ & 0 & 5 & 0 & 6 \\
Total & 61 & $0 \%$ & $5 \%$ & $0 \%$ & $6 \%$ \\
& $61 \%$ & 27 & 11 & 1 & 100 \\
& & $27 \%$ & $11 \%$ & $1 \%$ & $100 \%$ \\
\hline
\end{tabular}

Data yang diperoleh kemudian dianalisis menggunakan analisis korespondensi menggunakan piranti lunak SPSS 23 sehingga menghasilkan hubungan yang dapat dilihat pada Gambar 1.

Chi-Square Tests

\begin{tabular}{|l|r|r|r|}
\hline & Value & df & $\begin{array}{c}\text { Asymptotic } \\
\text { Significance } \\
\text { (2-sided) }\end{array}$ \\
\hline Pearson Chi-Square & $73.275^{\mathrm{a}}$ & 15 & .000 \\
Likelihood Ratio & 62.933 & 15 & .000 \\
Linear-by-Linear & 22.259 & 1 & .000 \\
Association & 100 & & \\
N of Valid Cases & & & \\
\hline
\end{tabular}

a. 18 cells $(75.0 \%)$ have expected count less than 5 . The minimum expected count is .02 .

Gambar 1. Hasil uji chi-square.

Pada gambar tersebut diketahui jika nilai chi-square 73,275 lebih besar dibandingkan nilai tabelnya yaitu 24, 9958 dengan derajat kebebasan 15 dan nilai signifikansi sebesar 0,05. Sehingga diketahui memang terdapat hubungan antara pemilihan moda transportasi dengan alasan pemilihan modanya dalam menggambarkan preferensi pemilihan moda transportasi oleh wisatawan.

Selanjutnya, dengan menggunakan piranti lunak yang sama kecenderungan preferensi dengan pemilihan moda transportasi beserta proporsi juga akan dianalisis. Hasilnya dapat dilihat pada Gambar 2. 
Row Profiles

\begin{tabular}{|l|r|r|r|r|r|}
\hline \multirow{2}{*}{ Preferensi } & \multicolumn{5}{|c|}{ Moda } \\
\cline { 2 - 6 } & \multicolumn{1}{|c|}{ Motor } & \multicolumn{1}{|c|}{ Mobil } & \multicolumn{1}{c|}{ Bus } & \multicolumn{1}{c|}{ Travel } & Active Margin \\
\hline Murah & .857 & .000 & .143 & .000 & 1.000 \\
Efisien & .828 & .138 & .017 & .017 & 1.000 \\
Bebas Macet & 1.000 & .000 & .000 & .000 & 1.000 \\
Nyaman & .000 & .667 & .333 & .000 & 1.000 \\
Santai & 1.000 & .000 & .000 & .000 & 1.000 \\
Terjangkau & .167 & .000 & .833 & .000 & 1.000 \\
Mass & .740 & .140 & .110 & .010 & \\
\hline
\end{tabular}

Gambar 2. Kecenderungan alasan pemilihan moda.

Gambar 2 menunjukkan bahwa preferensi dalam memilih moda transportasi sepeda motor adalah bebas macet dan santai dengan proporsi sebesar masing-masing 1 . Sedangkan untuk moda transportasi mobil preferensi terbesarnya adalah nyaman dengan proporsi sebesar 0,667. Untuk moda transportasi bus atau dalam penelitian ini Batik Solo Trans preferensi terbesarnya adalah terjangkau dengan proporsi 0,833 . Terakhir, moda transportasi travel preferensi terbesarnya adalah efisien dengan proporsi sebesar 0,017 .

Selanjutnya hasil analisis tersebut akan digambarkan dalam sebuah diagram yang menggambarkan hubungan antara preferensi dengan moda yang dipilih sehingga dapat diketahui moda beserta alasan pemilihannya. Hasilnya dapat dilihat pada Gambar 3.

Berdasarkan Gambar 3 tentang hubungan antara pemilihan moda transportasi oleh wisatawan dan alasannya, maka dapat disimpulkan sebagai berikut.

- Moda transportasi sepeda motor berkoresponden dengan alasan bebas macet, santai, murah, dan efisien.

- Moda transportasi travel berkoresponden dengan alasan efisien.

- Moda transportasi mobil berkoresponden dengan alasan nyaman.

- Moda transportasi Batik Solo Trans berkoresponden dengan alasan terjangkau.

Dengan diperolehnya kesimpulan di atas, maka dapat dijelaskan alasan sepeda motor menjadi moda transportasi yang paling banyak dipilih. Hal ini dikarenakan dengan menggunakan sepeda motor maka diperoleh perjalanan yang bebas macet, sebab sepeda motor dapat melakukan manuver diantara kendaraan bermotor lainnya dengan leluasa. Hal ini didukung dengan hasil penelitian yang dilakukan oleh Trianisari et al [15] dimana alasan dalam memilih moda transportasi salah satunya adalah faktor terbebas dari kemacetan. Sepeda motor juga cenderung mudah digerakkan kesana kemari sehingga dirasa lebih efisien dalam mengunjungi beberapa tempat. Selain itu, sepeda motor juga lebih sedikit mengkonsumsi bahan bakar sehingga dapat menghemat pengeluaran serta dengan pergerakan yang lebih baik, wisatawan dapat lebih santai dalam melakukan perjalanan. Hal tersebut diperkuat oleh Arofah et al [17] bahwa faktor yang melatarbelakangi pemilihan 
moda transportasi tertentu cenderung dipengaruhi oleh biaya yang harus dikeluarkan dan faktor kesukaan.

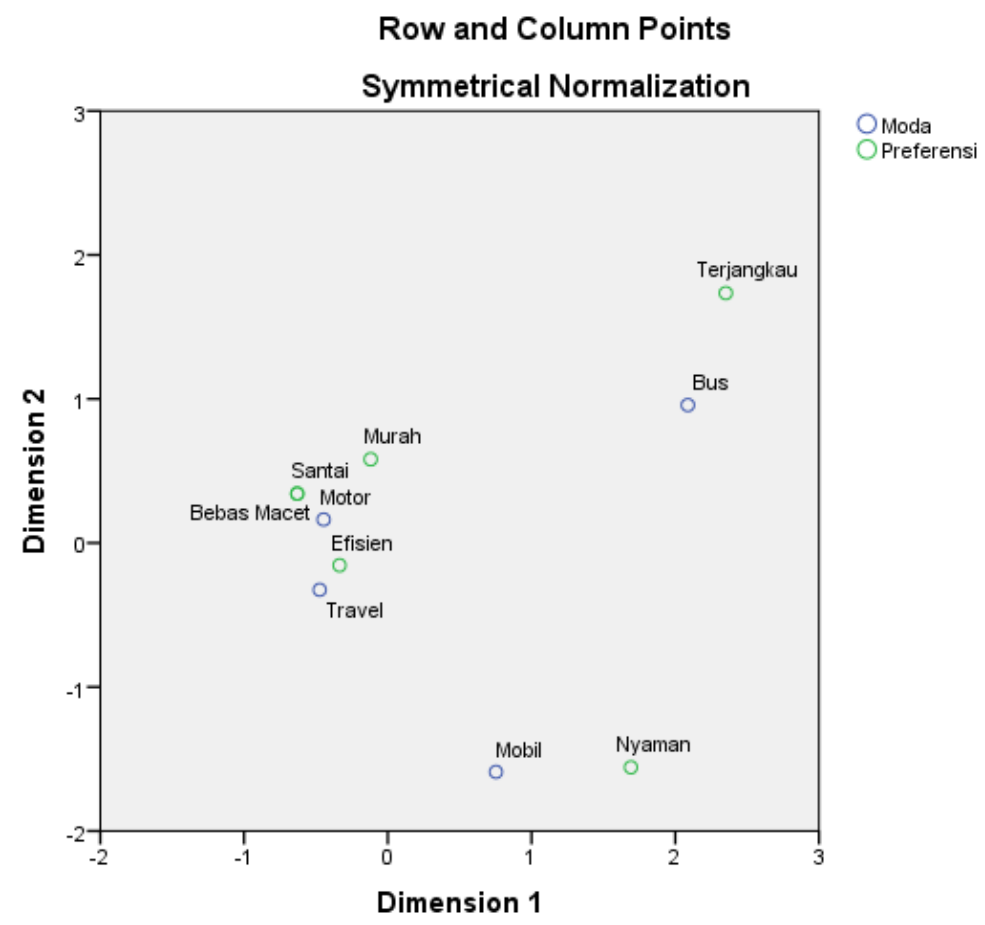

Gambar 3. Hubungan pemilihan moda dan alasannya.

Moda transportasi pilihan kedua adalah mobil dimana moda ini dianggap lebih nyaman dikendarai dibandingkan moda kendaraan lainnya. Namun kekurangannya adalah moda ini tidak murah dan rawan terjebak kemacetan. Meskipun begitu, menurut Trianisari et al [18] faktor status sosial-ekonomi pelaku perjalanan merupakah salah satu pendorong moda transportasi mobil masih dipilih untuk dipergunakan. Moda transportasi selanjutnya adalah Batik Solo Trans. Moda ini dipilih karena dianggap cukup murah dan mudah dijangkau bagi semua kalangan, namun kelemahannya adalah masih terbatasnya pilihan trayek yang dilayani sehingga tidak memungkinkan untuk melakukan pergerakan dengan efisien.

Moda yang terakhir adalah travel yang dianggap efisien. Travel menyediakan layanan antar jemput dari rumah hingga ke tempat tujuan sehingga memudahkan penggunanya. Namun kelemahan dari moda ini adalah penumpangnya memiliki tujuan yang berbeda sehingga penggunanya tidak dapat lebih santai menikmati perjalanan.

\section{Kesimpulan}

Sepeda motor menjadi moda transportasi yang paling banyak dipilih. Penggunaan moda sepeda motor memiliki keuntungan perjalanan yang bebas macet sebab sepeda motor dapat melakukan manuver dengan lincah serta volume kendaraan yang kecil sehingga dapat dengan leluasa bergerak diantara kendaraan bermotor lainnya dengan leluasa. Sepeda motor juga cenderung mudah dikendalikan dalam pergerakan kesana kemari sehingga dirasa lebih efisien dalam mengunjungi beberapa tempat. Selain itu, sepeda motor juga lebih 
sedikit mengkonsumsi bahan bakar sehingga dapat menghemat pengeluaran serta dengan pergerakan yang lebih baik, wisatawan dapat lebih santai dalam melakukan perjalanan.

Moda transportasi pilihan kedua adalah mobil dimana moda ini dianggap lebih nyaman dikendarai dibandingkan moda kendaraan lainnya. Namun kekurangannya adalah moda ini tidak murah dan rawan terjebak kemacetan. Walaupun begitu, moda ini dapat menunjukkan kelas sosial dari wisatawan yang memilih menggunakannya. Moda transportasi selanjutnya adalah bus atau dalam penelitian ini Batik Solo Trans. Moda ini dipilih karena dianggap cukup murah dan mudah dijangkau bagi semua kalangan, namun kelemahannya adalah masih terbatasnya pilihan trayek yang dilayani sehingga tidak memungkinkan untuk melakukan pergerakan dengan efisien.

Moda yang terakhir adalah travel yang dianggap efisien. Travel menyediakan layanan antar jemput dari rumah hingga ke tempat tujuan sehingga memudahkan penggunanya. Namun kelemahan dari moda ini adalah penumpangnya memiliki tujuan yang berbeda sehingga penggunanya tidak dapat lebih santai menikmati perjalanan.

\section{Referensi}

[1] Mammadov R The Importance of Transportation in Tourism Sector 7th Silk Road International Conference Diakses dari https://ssrn.com/abstract=2231334 pada 0601-2020

[2] Harun R 2008 Posisi Transportasi Dalam Pariwisata Diakses dari http://www.kabarindonesia.com/berita.php?pil=15\&jd=Posisi+Transportasi+dalam +Kepariwisataan\&dn=20081130071639 pada 03-10-2016

[3] Moeis H \& Fahmi A 2012 Model Layanan Transportasi Untuk Menarik Minat Wisatawan Berkunjung Ke Obyek Wisata Di Jawa Timur Jurnal Kebijakan dan $\begin{array}{lllll}\text { Manajemen } & \text { Publik } & 3 & 24-34 & \text { Diakses dari }\end{array}$ http://pps.uwp.ac.id/e/files/a67c8ac252c51ebe0b758340f69c03fa.pdf

[4] GNFI 2017 Terus Naik, Daya Saing Pariwisata Indonesia Peringkat 30 Dunia! Diakses dari https://www.goodnewsfromindonesia.id/2017/04/23/terus-naik-daya-saingpariwisata-indonesia-peringkat-30-dunia pada 02-01-2019

[5] World Economic Forum 2015 The Global Competitiveness Report 2015-2016 Diakses dari $\quad$ http://www3.weforum.org/docs/gcr/20152016/Global Competitiveness Report 2015-2016.pdf pada 06-01-2020

[6] Sim R 2014 Study: Singapore's public transport system one of world's most efficient Diakses dari https://www.straitstimes.com/singapore/transport/study-singaporespublic-transport-system-one-of-worlds-most-efficient pada 06-01-2020

[7] Noviani I 2012 Akses Transportasi Jadi Kendala Wisatawan Diakses dari https://www.beritasatu.com/home/86006/akses-transportasi-jadi-kendalawisatawan pada 19-04-2016

[8] Pemerintah Kota Surakarta 2012 RTRW Kota Surakarta tahun 2010-2030

[9] Winata A I 2016 Andalkan Wisata Kuliner, Disbudpar Solo Targetkan 4,5 Juta Wisatawan Diakses dari https://surakartadaily.com/2016/03/andalkan-wisatakuliner-disbudpar-solo-targetkan-45-juta-wisatawan/ pada 29 Maret 2016 
[10] Soedrajad Y H 2015 Solo Kekurangan Tenaga Ahli Transportasi Diakses dari https://nasional.tempo.co/read/685896/solo-kekurangan-tenaga-ahlitransportasi/full\&view=ok pada 30-03-2016

[11] Usman M 2013 Liburan Sekolah, Ini 7 Titik Kemacetan Solo Diakses dari https://www.solopos.com/solo-macet-liburan-sekolah-ini-7-titik-kemacetan-solo477256 pada $10-04-2017$

[12] Kusbiyantoro H 2008 Profil Wisatawan Di Pura Mangkunegaran Surakarta (Surakarta: Universitas Sebelas Maret)

[13] Ogilvie F W 1933 The Tourist Movement: an Economic Study (London : P. S. King)

[14] Marpaung 2002 Pengetahuan Kepariwisataan (Bandung: Alfabeta)

[15] Dewantoro D dan Widodo W 2015 Analisis Preferensi Masyarakat Terhadap Penggunaan Jasa Pelayanan Transportasi Bus AKDP Semarang-Kendal (Studi Kasus: Komuter Semarang-Kendal Tesis (Semarang: Universitas Diponegoro)

[16] Nurzukhrufa A 2014 Jangkauan Pelayanan Pasar Tradisional Yang Direvitalisasi Berdasarkan Preferensi dan Asal Konsumen Di Kota Surakarta Tugas Akhir (Surakarta: Universitas Sebelas Maret)

[17] Arofah N, Santoso A B dan Putro S 2012 Preferensi Penglaju Terhadap Moda Transportasi di Desa Tlogorejo Kecamatan Karangawen Kabupaten Demak GeoImage 1 44-9 DOI: 10.15294/geoimage.v1i1.945

[18] Trianisari M S, Ekasari A M dan Kusuma H E 2014 Preferensi Mahasiswa Terhadap Penggunaan Moda Transportasi Ke Kampus Temu IImiah IPLBI 13-6 Diakses dari https://temuilmiah.iplbi.or.id/wp-content/uploads/2014/11/TI2014-F-p013-016Preferensi-Mahasiswa-terhadap-Penggunaan-Moda-Transportasi-ke-Kampus.pdf pada 06-01-2020

[19] Indranata I 2008 Pendekatan Kualitatif Untuk Pengendalian Kualitas (Jakarta: Universitas Indonesia)

[20] Sugiyono 2008 Metode Penelitian Kuantitatif, Kualitatif dan R \& D (Bandung: Alfabeta) 